\title{
A STUDY ON ENERGY CONSUMPTION, ENERGY SAVING AND EFFECTIVENESS OF ALTERNATE ENERGY SOURCES IN DOMESTIC SECTOR OF INDIA
}

\author{
Anirban Nandy ${ }^{1}$, Poulomi Chaki ${ }^{2}$, O.P. Pandey ${ }^{3}$ \\ ${ }^{1}$ M. Tech Scholar, Department of Mechanical Engineering, Energy Technology, Birla Institute of Technology, Mesra, \\ India \\ ${ }^{2}$ Marketing Professional with Master's degree in Business Administration, Siliguri, India \\ ${ }^{3}$ Assistant Professor, Department of Mechanical Engineering, Birla Institute of Technology, Mesra, \\ India
}

\begin{abstract}
This paper studies the correlation between electricity consumption and consumer income and effectiveness of alternate energy sources in the domestic sector. India is a developing country and the demand for the energy is increasing regularly. Fossil fuels are the main sources of energy in this country. As fossils fuels become more costly and harder to find with several other disadvantages, it is required a shift from fossil fuels to non conventional energy. Solar energy is available in plenty and by using it electricity can be generated. This paper also attempts to use renewable energy at the domestic sector to aid the regular power supply.
\end{abstract}

Keywords: Consumer Income, Domestic Sector, Energy Consumption, Energy Saving, Renewable Energy.

\section{INTRODUCTION}

It has been predicted by the World Energy Forum that fossil fuels like oil, coal and gas reserves will be consumed completely in less than another 10 decades. Fossil fuels make modern life feasible. The abundant sources of energy work to generate steam and electricity. Fossil fuels are also used to fuel vehicles. It account for over $79 \%$ of the primary energy used in the world and $57.7 \%$ of the amount is consumed in the transportation and are decreasing rapidly. Non conventional energy sources have potential to reduce the energy problems being faced by the developing countries. Alternate energy sources like solar energy, wind energy, ocean energy, geothermal energy, biomass energy and fuel cell technology can be utilized to minimize energy shortage in India [1].

India stands fifth in the world in terms of wind power producer. The country has huge potential of generation from non conventional energy sources. Government of India is working efficiently to harness this potential. The Indian economy is the world's eleventh largest. It stands fourth in terms of purchasing power. Investors from developed countries are interested in India due to the low manpower cost and better quality production. India's energy demand is rising continuously. India uses its maximum energy in domestic, industrial and agricultural sectors in comparison to China, Japan, Russia and US [2].

Solar power generation is increasing in India. There will be a significant growth in the market in the next ten years, due to rising power demand and prices for fossil based fuels [3].
In terms of energy in India the demand/supply gap is around $8.2 \%$, which is affecting the growth of industrial sector and obstructing the progress of economy. India imports fossil fuels like coal, gas and oil resulting in a huge economical loss. As fossils fuels become more costly because of the fast depletion, the country is suffering financial loss. Therefore it is essential to adopt renewable energy technologies to deal with the energy crisis [4].

Utilization of renewable energy in domestic sector will aid the total energy requirement. For example, solar thermal systems can replace the conventional electrical geysers in domestic houses. Generation of electricity from solar PV panels can reduce the dependency on grid power [5]. With the reduction in energy cost there will be an increment in the energy savings. As a result monthly expense at a domestic level can be reduced.

Designing for a home renewable energy system is a method that involves analyzing the present electricity use and planning energy efficiency actions to reduce it, observing local codes and requirements, deciding if the system will operate on or off of the electric grid, and understanding the technology options available at the site.

The first step to take before using renewable energy is to see if there are ways to reduce the energy consumption. Proper observation for all conventional devices in the home is essential to find the more efficient way to optimize or reduce the consumption. It is to be indicated that CFLs are four times more efficient and last ten times longer than incandescent bulb [6]. 
Ministry of New and Renewable Energy contributes 30\% capital subsidy on capital expenditures for solar systems on rooftop in domestic houses for systems up to $100 \mathrm{~kW}$. The government also gives loans for 5 years at 5 percent per annum for 50 percent of the capital expenditure for residential implementation.

The objective of the work is to investigate the use of renewable energy in domestic section to supplement the energy requirement by reducing the demand-supply gap. This paper also demonstrates the present economical condition and the contribution of alternate energy in domestic electrification and associated savings gained.

\section{METHODOLOGY}

\subsection{Micro Generation}

Micro generation is a small scale generation of electric power. It is a process by which low carbon electrical power is produced, it is a process adopted by domestic consumers to meet their own requirements. Solar photovoltaic panels and small wind turbines are used primarily. Micro generation technologies can be installed easily. The utilization of micro generation technologies at the domestic level can supplement the regular grid supply.

\subsection{Solar energy in India}

Solar energy is the most useful of all the sources of non conventional energy. It will be one of the most useful sources of renewable energy even if we could utilize a small amount of it. Solar Photovoltaic cell transforms the solar energy directly to electrical energy. The solar photovoltaic cells in India are primarily used for irrigation purpose, drinking water, and rural electrification. In India for nearly 300 days in a year the sunshine is available.

\subsection{Indian Economy}

Power is the most important constituent of infrastructure essential for the economic growth and welfare of the country. The presence and development of sufficient infrastructure is crucial for the sustained growth of the Indian economy. Power sector of India is one of the most diversified in the world. Sources of power generation range from fossil fuel based conventional sources such as coal, oil and gas to renewable sources such as wind and solar. Hence sustained economic growth is resulting in high electricity demand in India.

\subsection{Experimental Procedure}

A survey has been done to understand the economical condition of a city known as Siliguri in West Bengal, India. The data of the monthly income along with the expenses and savings of 10 consumers from different level of the society were collected. Monthly expenses including electricity expense, food-groceries, transportation, internet and cell, cooking gas, child education and other expenses were considered. The monthly savings were calculated at each level. The details have been shown in Table -1. The case study is presented to utilize the renewable energy sources effectively at domestic sector to minimize the energy demand from grid, which in turn enhances the economic condition.

Table -1: Monthly expenses and savings at domestic level

\begin{tabular}{|c|c|c|c|c|}
\hline Sl. No. & Occupation & $\begin{array}{c}\text { Total number of members } \\
\text { in the family }\end{array}$ & $\begin{array}{c}\text { Total expenses per month } \\
\text { in rupees }\end{array}$ & $\begin{array}{c}\text { Savings per } \\
\text { month in rupees }\end{array}$ \\
\hline Home 1 & Doctor & 3 & 19,500 & 30,500 \\
\hline Home 2 & Irrigation officer & 4 & 19,700 & 30,300 \\
\hline Home 3 & Professor & 4 & 18,100 & 31,900 \\
\hline Home 4 & Scientist & 3 & 15,840 & 24,160 \\
\hline Home 5 & Sub assistant engineer & 4 & 15,750 & 24,250 \\
\hline Home 6 & School teacher & 3 & 15,388 & 19,162 \\
\hline Home 7 & Businessman & 5 & 13,048 & 16,952 \\
\hline Home 8 & Junior engineer & 4 & 10,563 & 14,437 \\
\hline Home 9 & Businessman & 6 & 9,898 & 10,102 \\
\hline Home 10 & Clerk & 5 & 8,213 & 6,787 \\
\hline
\end{tabular}

\section{RESULTS AND DISCUSSION}

\subsection{Consumer income and expenditure}

The monthly savings of all the families depend on the expenditure, less the expenses more the savings. Electricity expense, food-groceries, child education and cooking gas are the major expenditures at domestic sector, among which electricity expense is subject of interest for this paper. The monthly expense of a family is shown in Fig. -1 .

\subsection{Electricity expense}

Electricity is one of the important requirements. If the electricity expense is increased there will be a decrease in the total savings of a family. The electricity expenses of all the families are shown in Table -2 . 


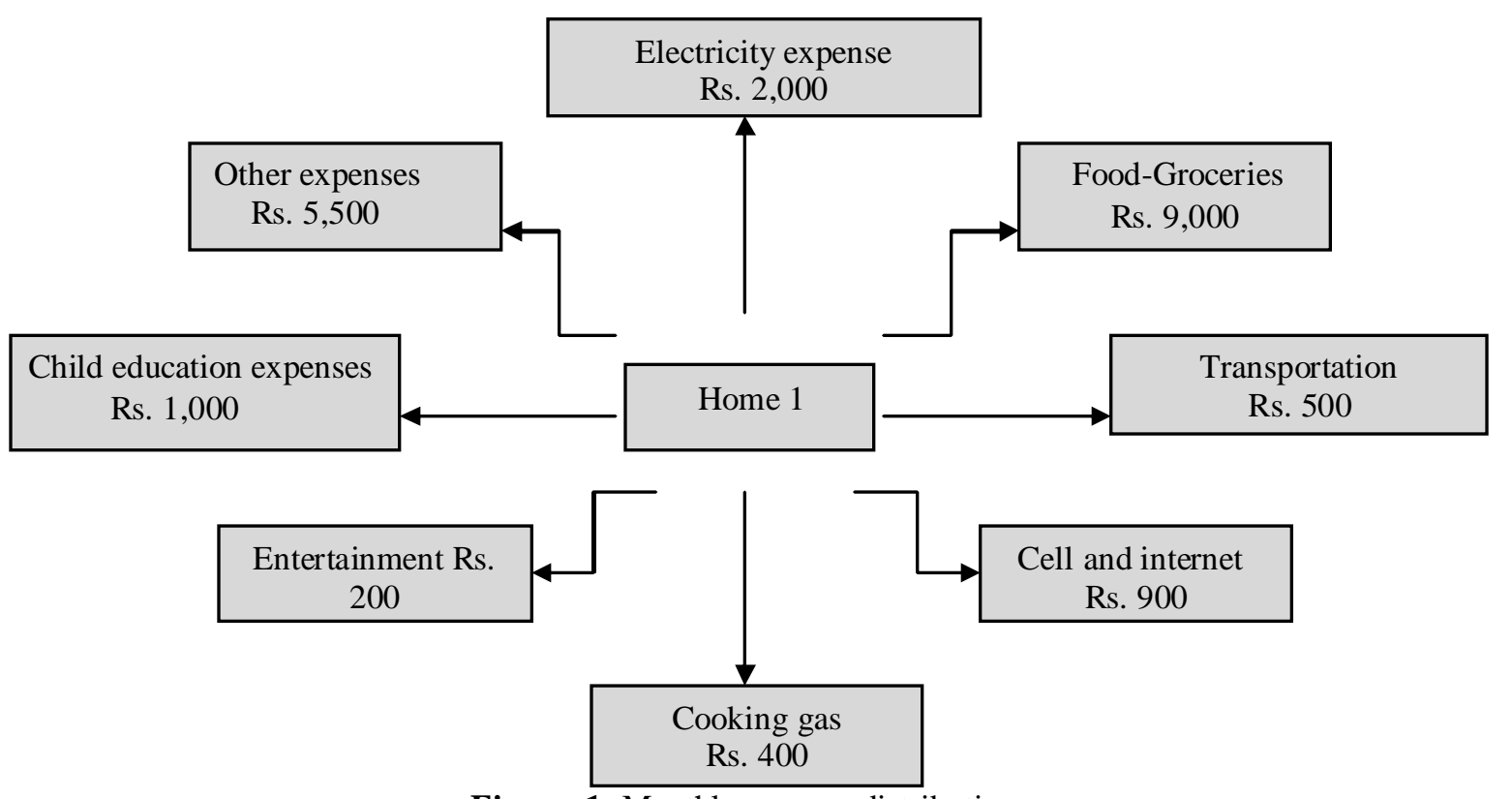

Figure -1: Monthly expense distribution

Table -2: Electricity expense

\begin{tabular}{|c|c|c|c|}
\hline Name of the person & Total monthly expenses in rupees & Electricity expense in rupees & $\begin{array}{c}\text { \% electricity expense of the } \\
\text { total expenses }\end{array}$ \\
\hline Home 1 & 19,700 & 2,000 & 10.25 \\
\hline Home 2 & 19,500 & 2,100 & 10.65 \\
\hline Home 3 & 18,100 & 1,500 & 8.28 \\
\hline Home 4 & 15,840 & 1,440 & 9.09 \\
\hline Home 5 & 15,750 & 1,300 & 8.25 \\
\hline Home 6 & 15,388 & 1,290 & 8.38 \\
\hline Home 7 & 13,048 & 1,050 & 8.04 \\
\hline Home 8 & 10,563 & 965 & 9.13 \\
\hline Home 9 & 9,898 & 900 & 9.09 \\
\hline Home 10 & 8,213 & 865 & 10.53 \\
\hline
\end{tabular}

3.3 Total energy consumption in domestic houses using green energy

Table -3: Total energy consumption per day (Case I)

\begin{tabular}{|c|c|c|c|c|}
\hline Items & Wattage & Nos. & Approximate working hours per day & Energy consumption per day (kWh) \\
\hline CFL lamps & 15 & 10 & 2 & 0.3 \\
\hline Fluorescent tube & 35 & 7 & 3 & 0.735 \\
\hline Fan & 60 & 10 & 3 & 1.8 \\
\hline Computer & 150 & 4 & 4 & 2.4 \\
\hline Printer & 70 & 1 & 1 & 0.07 \\
\hline LED Television & 250 & 4 & 5 & 5 \\
\hline Water cooler & 1000 & 1 & 5 & 5 \\
\hline Motor & 1100 & 2 & 1 & 2.2 \\
\hline
\end{tabular}




\subsection{Total energy consumption in conventional houses}

Table -4: Total energy consumption per day (Case II)

\begin{tabular}{|c|c|c|c|c|}
\hline Items & Wattage & Nos. & Approximate working hours per day & Energy consumption per day (kWh) \\
\hline Incandescent lamps & 60 & 10 & 2 & 1.2 \\
\hline Fluorescent tube & 40 & 7 & 3 & 2.1 \\
\hline Ceiling fan & 70 & 10 & 3 & 2.4 \\
\hline Computer & 150 & 4 & 4 & 0.08 \\
\hline Printer & 80 & 1 & 5 & 6 \\
\hline Television & 300 & 4 & 5 & 5 \\
\hline Water cooler & 1000 & 1 & 1 & 3 \\
\hline Motor & 1500 & 2 & & 0.08 \\
\hline
\end{tabular}

\section{Case I:}

Total energy consumption $=0.3+0.735+1.8+2.4+0.07$ $+5+5+2.2=17.505 \mathrm{kWh} /$ day

Monthly energy consumptions in $\mathrm{kWh}=17.505 \times 30=$ $525.15 \mathrm{kWh}$

Case II:

Total energy consumption $=1.2+0.84+2.1+2.4+0.08+$ $6+5+3=20.62 \mathrm{kWh} /$ day

Monthly energy consumptions in $\mathrm{kWh}=20.62 \times 30=618.6$ $\mathrm{kWh}$

Total saving in energy consumption $=618.6-525.15=$ $93.45 \mathrm{kWh}$

\subsection{Design of solar photovoltaic system}

Step1:

Load determination: To find the demand of the load in total, individual ac and dc loads with usage hours of appliances are taken. Using the following equation the calculation of the total load is done.

Total calculated load $=($ ac load $\times$ hours of operation per day $+($ dc load $\times$ hours of operation per day $)$

\section{Step 2:}

Selection of the battery size: Calculation for the number of batteries is required. The days without sunshine, the days of autonomy are decided.

Capacity of required battery bank $=($ average Wh per day $\times$ days of autonomy) / (battery voltage $\times$ depth of discharge)

Total amount of batteries in number:

The minimal voltage of the battery should be known to calculate the number of batteries connected in series.
Number of batteries connected in series $=$ (voltage of the system) / (nominal voltage of battery)

Again, the knowledge of Ah value of the battery is needed to calculate the number of batteries in parallel.

Number of batteries connected in parallel $=(\mathrm{Ah}$ rating of battery bank) / (Ah of battery)

Step 3:

Selection of the solar array size: The array sizing should be such that the Ah demand in average per day and the minimal operating voltage are acquired. The average Ah per day can be acquired as follows.

Average Ah per day the array supplies = (daily average taken from the battery) / (efficiency of the battery)

Peak amps of the array = (average Ah per day supplied by the array) / (peak sunshine hours per day)

Parallel module can be calculated as follows.

Module connected in parallel $=$ (peak amps of the array) $/$ (peak amps per module)

Series module can be calculated as follows.

Module connected in series $=($ voltage of the battery bank $) /$ (nominal module voltage)

Step 4:

Selection of the array inclination: Usually the PV module is positioned in such a way that northern hemisphere in south and southern hemisphere in north. Therefore, the PV module is placed in such a way so that at noon it faces the sun. In winter, pitching at a sharper angle increases the output and in summer, pitching at a slighter angle gives more output.

Step 5:

System design: After calculating the above parameters including the battery bank size, the array size and array position the system design can be estimated finally connecting all the components. 


\section{CONCLUSION}

In this paper the economical assessment has been done at domestic level to understand the energy consumption and the effect of alternate energy particularly solar energy and the use of CFLs to help the consumer save energy. From the tabular demonstration and calculation shown above it is clear that non conventional buildings with the aid of solar energy can make the customer independent of paying the price to the grid at a certain level. Therefore, a partial shift to renewable energy sources can make India economically healthy. Green energy revolution in India can improve the standard of living in domestic sector.

\section{ACKNOWLEDGEMENT}

This research was made possible thanks to the support of the high quality equipments available and keen interest of the authors with several other resources.

\section{REFERENCES}

[1]. Ashwani Kumar, Kapil Kumar, Naresh Kaushik, Satyawati Sharma and Saroj, "Renewable energy in India: Current status and future potentials", Renewable and Sustainable Energy Reviews, 14, pp. 2434-2442, 2010.

[2]. R. K. Gera, Dr H. M. Rai, Yunus Parvej and Himanshu Soni, "Renewable Energy Scenario in India: Opportunities and Challenges", Indian Journal of Electrical and Biomedical Engineering, 1(1) pp. 10-16, 2013.

[3]. Swami Prakash Srivastava and Surat Prakash Srivastava, "Solar Energy and its Future Role in Indian Economy", International Journal of Environmental Science: Development and Monitoring, 4(3) pp. 81-88, 2013.

[4]. A. Srinivasa Rao, S. V. L. Narasimham and B. Suresh Kumar, "A Realistic Estimation of Energy Saving with Renewable Energy Sources in Domestic Sector", International Journal of Electrical Engineering \& Technology, 4(1), pp. 124-130, 2013.

[5]. Jigneshkumr R. Chaudhari, Prof. Keyur D. Tandel and Prof. Vijay K. Patel, "Energy saving of Green Building Using Solar Photovoltaic Systems", International Journal of Innovative Research in Science, Engineering and Technology, 2(5), pp. 1407-1416, 2013.

[6]. Charles Ndungu, John Nderu and Livingstone Ngoo, "Effects of Compact Fluorescence Light (Cfl) Bulbs on Power Quality", Journal of Energy Technologies and Policy, 2(3), pp. 1-6, 2012.

\section{BIOGRAPHIES}

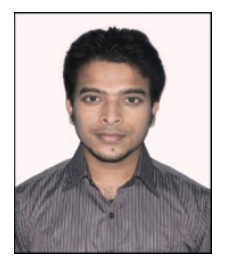

Anirban Nandy is a Master's in Technology Scholar in Birla Institute of Technology, Mesra, Ranchi, India. His research interests include renewable energy and drying technology. He has published several research papers in national and international journals.

Email id: mtet10012.14@bitmesra.ac.in

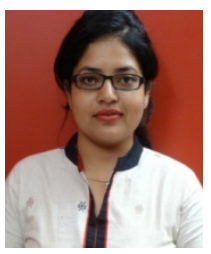

Poulomi Chaki is a Marketing Professional with Master's degree in Business Administration, Siliguri, India. She received her MBA from West Bengal University of Technology, Kolkata, West Bengal, India.

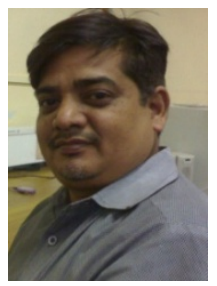

O. P. Pandey is an Assistant Professor, Department of Mechanical Engineering, Birla Institute of Technology, Mesra, India. $\mathrm{He}$ received his Master's in Engineering from MNNIT Allahabad. His research interests include Turbo machines and design of process equipments. 